\title{
UNGKAPAN-UNGKAPAN METAFORIS DALAM PUISI-PUISIKARYA AGUS R. SARDJONO
}

\author{
Supriyadi \\ FBIB Universitas Negeri Gorontalo \\ email: supriyadiung@yahoo.co.id
}

\begin{abstract}
Abstrak
Penelitian ini bertujuan mendeskripsikan ungkapan metaforis dalam puisi-puisi karya Agus R. Sardjono yang mewakili ruang persepsi manusia. Jenis penelitian ini adalah deskriptif kualitatif. Sumber data penelitian adalah kumpulan puisi karya Agus R. Sardjono yang berjudul "Suatu Cerita dari Negeri Angin" berjumlah 39 buah puisi. Tahapan penelitian meliputi: (a) identifikasi simbol metaforis, (b) penandaan satuansatuan segmentasi, dan (c) deskripsi makna metaforis berdasarkan klasifikasi Halley. Hasil penelitian menunjukkan bahwa dalam puisi-puisi karya Agus R. Sardjono terdapat simbol-simbol ungkapan metaforis yang mewakili ruang persepsi manusia. Ditemukan 65 simbol ungkapan metaforis yang tersebar pada sembilan jenis ruang persepsi manusia. Ungkapan metaforis dimaksudkan untuk memperoleh efek etis dan estetis dalam puisi. Efek etis dan estetis disampaikan dengan menggunakan ungkapan metaforis yang melambangkan sesuatu yang konkret untuk tujuan yang abstrak atau sebaliknya, yaitu untuk tujuan yang abstrak dengan menggunakan lambang-lambang yang konkret.
\end{abstract}

Kata kunci: ungkapan metaforis, simbol, puisi, ruang persepsi manusia

\section{METAPHORICAL EXPRESSIONS IN AGUS R. SARDJONO'S POEMS}

Abstract

This study aims to describe metaphorical expressions in Agus R. Sardjono's poems that represent human perception space. This was a qualitative descriptive study. The data source was Suatu Cerita dari Negeri Angin, an anthology of poems written by Agus R. Sardjono, consisting of 39 poems. The research stages included: (a) metaphorical symbol identification, (b) segmentation unit marking, and (c) metaphorical meaning description based on Halley's classification. The findings show that in Agus R. Sardjono's poems, there are symbols of metaphorical expressions representing human perception space. There are 65 symbols of metaphorical expressions spread in nine types of human perception space. The metaphorical expressions are intended to obtain ethical and aesthetical effects in the poems. These two effects are presented through the use of metaphorical expressions symbolizing something concrete with an abstract purpose or, on the contrary, an abstract purpose using concrete symbols.

Keywords: metaphorical expressions, symbols, poems, human perception space

\section{PENDAHULUAN}

Kecenderung penggunaan bahasa dan sastra adalah mengikuti hukum alam. Hal itu layaknya terjadi pada peristiwa sebuah atom yang mencari void. Menurut kaum atomik terdapat dua unsur utama yang membentuk realita, yakni atom dan void. Pandangan yang menyatakan bahwa peristiwa alamiah atom untuk menempati void telah dinyatakan, antara lain oleh Newton. Newton menyatakan bahwa $a$ body at rest remains at rest and a body in motion continues to move at constant speed along a straight line, unless in either case, the body is acted upon by an outside force (Wahab, 2006a:25). Hal itu menunjukkan bahwa suatu atom yang bergerak mencari dan menempati void selamanya terus 
berusaha mendapatkan jalan yang lurus dan sesingkat mungkin. Peristiwa serupa terjadi pula pada fenomena bahasa yang secara terus-menerus mencari jalan pintas yang sesingkat mungkin untuk mencapai tujuan komunikasi.

Dengan prinsip work less but get more ataupun the principle of minimun ease of articulation peristiwa jalan pintas itu terjadi pada bidang-bidang bahasa, yakni bidang fonologi, morfologi, sintalsis, dan tindak tutur metaforis. Pada bidang fonologi tampak pada proses asimilasi, lenisi, apokope, dan sinkope. Pada bidang morfologi peristiwa seperti itu terjadi pada peristiwa blending dan clipping. Pada bidang sintaksis hal itu terjadi pada kalimat imperatif, elipsis, dan question-tag dalam bahasa Inggris. Sedangkan pada tindak tutur metaforis hal itu terjadi pada bentuk nominatif yang terdiri atas nominatifsubjektif dan nominatif-objektif, bentuk predikatif, dan bentuk kalimatif.

Sebagai kajian linguistik, penerapan tindak tutur metaforis yang menggunakan prinsip the principle ease of articulation banyak ditemukan dalam bidang sastra. Dalam puisi misalnya, terdapat pernyataan-pernyataan metaforis yang sering digunakan penyair ketika ia mencipta suatu sajak atau pun puisi. Pernyataan metaforis sebagai gejala kebahasaan dalam puisi direalisasikan dalam bentuk lambang atau simbol atau signifier yang mengandung makna yang dimaksudkan atau signified. Dengan pernyataan metaforis, kita dapat mengatakan bahwa puisi kaya akan metafora.

Salah satu alasan mengapa puisi kaya akan simbol adalah bahwa dalam puisi terdapat percampuran antara dunia nyata dan dunia kias, antara makna sesungguhnya dan makna kias. Dalam kaitan itu, Levin (1977) menyatakan bahwa In the poem, there is a mixture of real word and imaginary world reference, or the world of the poem is entirely one of the imagination; but some features, normally of the real world have been transfered into the imaginary world of the poem. Walaupun demikian, antara puisi dan metafora dapat dibedakan antara satu dan lainnya. Puisi bukanlah metafora dan begitu pula sebaliknya metafora juga bukan puisi. Dalam puisi terkandung kata-kata yang bernuansa metafora. Metafora merupakan bagian dari kata-kata dalam puisi. Jadi metafora dalam puisi terbatas pada larik-larik dan bait-bait yang mengandung pernyataan metaforis dalam suatu puisi (dimodifikasi dari Wahab, 2006b:74).

Dalam penggunaan bahasa terdapat dua hal penting yang saling berkaitan, yaitu lambang atau simbol atau signifier yang dijelaskan dan makna yang dimasudkan atau signified yang menjelaskan. Signifier adalah bentuk dan sigified adalah makna (Wahab, 2006c). Bentuk adalah sesuatu yang kongkrit, tetapi makna adalah sesuatu yang tersembunyi atau abstrak. Achen (1978) menyatakan bahwa A symbol was originally a thing, a sign, or a word used for mutual recognition and with understood meaning. Simbol-simbol yang digunakan dalam ungkapan kata-kata perlu diketahui maknanya, terutama makna universalitasnya. Makna universal adalah makna yang dapat diterima dan dimengerti oleh budaya manapun. Dalam hal itu, Landrit menyatakan bahwa:

"Symbolisme is the science of the relation which unite the created world with God, the material world with the supernatural; the science of the harmonies existing between the diverse parts of the universe (correspndence and analogies), operating within the process of involution, that is of the materiality of all things."

(Cirlot, 1962)

Sebenarnya kata simbol itu sendiri mempunyai banyak konotasi. Satu simbol pada intinya merupakan sesuatu hal, suatu tanda atau kata yang digunakan untuk pengetahuan dan makna yang samasama diketahui. Simbol dapat mewakili 
alat, tanda, pesan, atau bentuk pengetahuan, baik linguistik maupun nonlinguistik, internasional maupun uniinternasional (Achen, 1978).

Selanjutnya dalam hubungannya dengan pengertian simbol perlu dibedakan antara makna simbol dan makna simbolisme atau metaforis. Menurut Coomaraswamy (Cirlot, 1962) simbolisme merupakan seni berpikir menurut imaji. Sedangkan simbol merupakan ungkapan yang tepat dan terealisasikan yang berhubungan dengan kehidupan inti dan pokok. Dengan kata lain, simbol merupakan lambang umum bukan sebagai mimpi, bukan sebagai bayangan, tapi sebagai suatu kehidupan realistis.

Dalam puisi terdapat banyak pernyataan simbolik. Russel (1966:108) menyatakan bahwa many poems are based on the symbolic statements. Pernyataan simbolik dalam puisi tersebut sebagai tempat lahirnya metafora. Simbol-simbol kebahasaan yang digunakan dalam puisi itu merujuk pada pengertian metafora. Simbol metafora yang lahir dalam puisi dapat mengacu pada semantik universal dan semantik yang terikat budaya. Simbol-simbol yang digunakan dalam puisi merupakan kategori metafora nominatif, baik sebagai subjek maupun objek. Simbol sebagai metafora nominatif-subjektif adalah simbol yang digunakan pada puisi yang berkedudukan sebagai subjek. Sedangkan simbol sebagai metafora nominatif-objektif adalah simbol yang berfungsi sebagai objek dalam suatu kalimat.

Menurut Cirlot (1962) terdapat tiga jenis simbol dengan tingkatan yang berbeda, yakni (a) simbol konvesional, (b) simbol aksidental, dan (c) simbol universal. Dalam penelitian ini, simbol yang dibahas adalah masalah simbol universal yang klasifikasinya dipaparkan menurut hasil pengamatan penulis. Klasifikasi simbol yang dimaksud adalah klasifikasi menurut Halley (1980) yang mencakup sembilan jenis kategori, yakni (a) being, (b) cosmos, (c) energy, (d) substance, (e) terrestrial, $(f)$ object, $(g)$ living, $(h)$ animate, dan (i) human.

Penggunaan simbol-simbol metafora untuk mengetahui ruang persepsi manusia dalam penciptaan puisi dapat mengikuti model Halley di atas yang terdiri atas sembilan hirarkhi. Pertama simbol pada ruang persepsi kategori being yang merupakan simbol kebahasaan yang tak langsung melambangkan hal-hal yang bersifat abstrak dengan predikasi ada atau nomina yang bersifat abstrak, seperti kebenaran, kecantikan, kegelapan, kejujuran, kesetiaan, kemuliaan, kebahagiaan, dan seterusnya.

Kedua simbol pada ruang persepsi kategori cosmos. Cosmos berada pada kategori medan semantik universal tidak hanya ada, melainkan juga menempati ruang di jagad raya yang dapat diamati oleh indra kasat mata, meskipun berada pada tempat yang jauh, misalnya matahari, bintangbintang, bulan, Jupiter, Saturnus, dan lainnya dalam tatanan tatasurya.

Ketiga simbol pada ruang persepsi kategori energy. Energy berupa kategori berpredikasi yang tidak saja ada dan menempati ruang, tetapi juga mempunyai predikasi bergerak dan menggerakan sesuatu, misalnya cahaya, api, angin, ombak, dan seterusnya. Kategori di bawahnya adalah simbol pada ruang persepsi kategori substance, yakni kategori yang selain memiliki predikasi ada, menempati ruang, dan bergerak, ia juga mempanyai sifat lembam, misalnya air, es, udara, hidrogen, oksigen, karbondioksida, dan seterusnya.

Urutan berikut adalah simbol pada kategori terrestrial, yakni hamparan yang terikat oleh bumi, seperti gunung, sungai, laut, danau, dan seterusnya. Predikasi yang dimiliki oleh kategori ini adalah terhampar.

Selanjutnya adalah simbol pada kategori object. Sifat-sifat kategori ini ada- 
lah selain memiliki sifat-sifat yang ada pada kategori-kategori yang disebutkan di atas, kategori object ini mempunyai bentuk yang pasti yang mencakup segala macam benda, seperti batu, emas, perak, perunggu, besi, bola, meja dan barangbarang meneral lainnya. Semua benda yang tercakup dalam dalam kategori ini mempunyai sifat pecah.

Kategori semantik berikutnya di bawah object yang dilambangkan oleh simbol metafora adalah kategori living. Kategori ini selain ada, menempati ruang, bergerak, terhampar, memiliki bentuk yang pasti, juga berpredikasi tumbuh sebagai organik yang hidup. Semua benda yang mewakili tumbuh-tumbuhan termasuk dalam kategori ini, misalnya buahbuahan, bunga-bungaan, sayur-sayuran, dan sejenisnya.

Kategori di bawah living yang dilambangkan oleh simbol metafora adalah kategori animate. Simbol metafora ini melambangkan sesuatu selain memiliki ciri-ciri kategori di atasnya, juga memiliki ciri yang tak terdapat pada kategori-kategori tersebut, yakni bernyawa, predikasi berjalan dan lari. Semua benda yang termasuk dalam kategori ini mencakup segala jenis binatang, seperti naga, singa, harimau, sapi, kuda, kerbau, kambing, kucing, dan sejenisnya.

Urutan terakhir adalah simbol metafora pada kategori human. Human atau manusia dengan segala perilakunya menunjukkan berbagai macam perbuatan yang mungkin tidak terdapat pada kategori-kategori di atasnya. Kategori human termasuk kategori yang rumit, karena pengalaman manusia sebagai mahluk individu berbeda dengan individu lainnya. Oleh karena itu, kategori human diberikan predikasi berpikir sebagai sifat yang tidak terdapat pada kategori-kategori pada urutan sebelumnya.

Penggunaan model Halley tentang simbol-simbol metafora untuk mengetahui ruang persepsi manusia dalam penciptaan puisi yang terdiri atas sembilan hirarkhi tersebut didasarkan pada beberapa pertimbangan berikut. Teori Halley dengan semantik universalnya merupakan teori paling baik untuk melihat ruang persepsi manusia pencipta ungkapan bahasa simbolis. Teori itu mampu melihat hasil interaksi manusia dengan alam lingkungannya dalam hal penciptaan ungkapan yang berciri simbolis. Seberapa besar hasil interaksi manusia dalam sistem ekologinya akan jelas dan tepat dengan menggunakan teori itu.

Hal tersebut bukan berarti menyepelekan teori-teori lain, seperti teori Quintilian dan teori Aristoteles yang memandang metafora sebagai dikotomi hidup dan mati atau yang umum dan yang khusus. Kedua teori itu mungkin terbatas ruang lingkupnya dibandingkan dengan teori yang dikembangkan Halley (1980) tersebut. Sistem pengkategorian atas gejala dan fenomena di lapangan tidak akan mampu dipecahkan oleh kedua teori Quintilian dan terori Aristoteles.

Berdasarkan paparan di depan, data yang digunakan sebagai landasan pembahasan dalam makalah ini adalah lariklarik puisi yang mengandung ungkapanungkapan metaforis. Sumber datanya adalah kumpulan puisi Agus R. Sardjono dengan judul Suatu Cerita dari Negeri Angin yang berjumlah 39 buah puisi. Prosedur yang dilalui adalah (a) memahami simbolsimbol yang berupa kata-kata metaforis, (b) memahami deskripsi makna yang dikandungnya, (c) menandai satuan-satuan segmentasi, baik berupa simbol maupun makna yang dimiliki kata-kata metaforis, dan (d) mengklasifikasi simbol-simbol dan maknanya sesuai dengan klasifikasi menurut Halley yang mencakup sembilan jenis kategori di depan.

\section{METODE}

Jenis penelitian ini adalah deskriptif kualitatif. Dalam hal ini peneliti berusaha mengungkap ungkapan-ungkapan meta- 
foris yang terdapat pada kumpulan puisi Agus R. Sardjono. Sumber data adalah kumpulan puisi karya Agus R. Sardjono yang berjudul "Suatu Cerita dari Negeri Angin" yang berjumlah 39 buah puisi. Data penelitian adalah segmen-segmen puisi-puisi Agus R. Sardjono yang mengandung ungkapan-ungkapan metaforis. Sumber data tersebut dimaksudkan untuk mendapatkan korpus bagi masalah dan tujuan penelitian. Instumen utama penelitian ini adalah peneliti sendiri. Teknik pengambilan data adalah dokumentasi dan observasi langsung pada sumber data, yakni kumpulan puisi karya Agus R. Sardjono yang berjudul "Suatu Cerita dari Negeri Angin" yang berjumlah 39 buah puisi. Selanjutnya, observasi juga dilakukan atas biografi atau kehidupan pribadi penyair sebagai bahan untuk mendeskripsikan data semantik. Prosedur yang dilalui dari pengambilan data sampai dengan pemaknaan data adalah (a) mengidentifikasi simbol-simbol yang berupa kata-kata metaforis, (b) memahami simbol-simbol yang berupa katakata metaforis, (c) memahami deskripsi makna yang dikandungnya, (d) menandai satuan-satuan segmentasi, baik berupa simbol maupun makna yang dimiliki kata-kata metaforis, dan (e) mengklasifikasi simbol-simbol dan maknanya sesuai dengan klasifikasi menurut Halley (1980) yang mencakup sembilan jenis kategori di depan. Analisis data didasarkan pada tiga proses, yakni proses reduksi, proses sajian data, dan proses verifikasi dengan berfokus pada penelitian metafora dalam kumpulan puisi karya Agus R. Sardjono.

\section{HASIL DAN PEMBAHASAN}

Hasil penelitian ini adalah berupa paparan ungkapan-ungkapan metaforis dalam simbol-simbol pada puisi-puisi Agus R. Sardjono berdasarkan ruang persepsi manusia Model Halley.

Dari hasil penenelitian terhadap 39 buah puisi hasil karya Agus R. Sardjono diperoleh informasi bahwa terdapat 65 simbol yang mengandung ungkapan metaforis. Deskripsi ruang persepsi pada ungkapan-ungkapan metaforis ciptaan Agus R. Sardjono dalam puisi-puisinya tersebut disajikan pada Tabel 1.

Tabel 1. Deskripsi Ruang Persepsi Ungkapan Metaforis

\begin{tabular}{lcc}
\hline $\begin{array}{c}\text { Ruang Persepsi } \\
\text { Manusia }\end{array}$ & $\begin{array}{c}\text { Jumlah } \\
\text { yang } \\
\text { Diperoleh }\end{array}$ & $\begin{array}{c}\text { Persentase } \\
\mathbf{( \% )}\end{array}$ \\
\hline 1.BEING & 11 & 16.92 \\
2. COSMOS & 5 & 7.70 \\
3. ENERGY & 6 & 9.23 \\
4.SUBSTANCE & 3 & 4.61 \\
5.TERRESTRIAL & 5 & 7.70 \\
6. OBJECT & 19 & 29.23 \\
7. LIVING & 4 & 6.15 \\
8. ANIMATE & 3 & 4.61 \\
9. HUMAN & 9 & 13.85 \\
J U M L A H & 65 & $100 \%$ \\
\hline
\end{tabular}

Berdasarkan paparan tabel di atas tampak bahwa simbol-simbol yang terbanyak adalah pada kategori objek, yakni 19 simbol atau sekitar $29.23 \%$ dari jumlah simbol yang ditemukan, yakni 65 simbol. Selanjutnya pada kategori being, simbol yang ditemukan adalah 11 buah atau sekitar $16.92 \%$, yang disusul oleh kategori human dengan jumlah simbol 9 buah atau $13,85 \%$, kemudian yang berikut adalah kategori energy dengan jumlah 6 simbol atau 9.23\%. Kategori cosmos dan terrestrial masing-masig adalah 5 simbol atau $7.70 \%$. Kategori living berjumlah 4 simbol atau $6.15 \%$ dan terakhir adalah kategori substance dan kategori animate dengan jumlah yang sama, yakni 3 simbol atau $4,61 \%$.

\section{Simbol-simbol pada Kategori Being}

Simbol-simbol metaforis pada kategori being mencakup: (a) simbol usia, (b) simbol hitam, (c) simbol gelap atau kegelapan, (d) simbol surga, (e) simbol perjalanan, (f) simbol kehidupan, (g) simbol malam, 
(h) simbol kekuatan dan kekuasaan, (i) simbol bayangan, (j) simbol bahagi, dan (k) simbol kecantikan. Deskripsi wujud simbol metaforis kategori being disajikan pada uraian contoh berikut.

Simbol usia melambangkan tingkat perkembangan dan eksitensi manusia yang mengalami empat fase dalam hidupnya, yakni fase membesar, sempurna, menyusut, dan hilang atau punah atau mati. Larik puisi yang mengandung metafora atau simbol usia adalah sebagai berikut.

“Dante, Descartes, Kant, Hegel... Ia dijemput usia senja"

(Surat Paman Veteran pada Setengah Abad Kemerdekaan. bait 1, larik 1213)

Kata hitam melambangkan ide kreasi yang diliputi oleh ketakutan, kesengsaraan, dan atau kematian. Metafora dalam larik puisi yang memiliki simbol hitam adalah sebagai berikut.

"mendapati anak-anak mengeras seperti baja hitam"

(Negeri Bayang-Bayang. bait 1, larik 17)

Simbol gelap semalaman dan kegelapan pada metafora semalaman itu melambangkan kekacauan dan ketidakmenentuan Larik puisi yang mengandung simbol ataupun metafora gelap atau kegelapan adalah sebagai berikut.

"berdisko semalaman? Aku pun beringsut menjauh"

(Surat Paman Veteran pada Setengah Abad Kemerdekaan. bait 2, larik 8)

"menembus barisan naga api dan sihir kegelapan"

(The Hoplessness of Sleeping Beauty. bait 1, larik 12)

Simbol surga pada kemerdekaan melambangkan spirit atau dorongan yang baik. Adapun simbol surga terdapat pada larik puisi berikut.

"alangkah manis kemerdekaan. Sly, how do think about us?"
(Di Planet Senen, Hollywoodku Sayang. bait 3, larik 1)

Simbol perjalan pada perlayaran menggambarkan keinginan dan ungkapan hasrat seseorang untuk selalu mendapatkan perubahan dan pengalaman baru. Simbol ini terdapat pada pada larik puisi berikut.

"hingga kapal-kapal bisa berlayaran ke negeri-negeri seberang"

(Pinangan Angin. bait 2, larik 6-7)

Simbol kehidupan air melambangkan berfungsinya nafas dan tumbuh, serta berkembangnya fisik secara normal. Adapun simbol kehidupan yang digunakan penyair terdapat pada larik puisi berikut.

"Rumah yang tentram, teh manis keemasan dan air putih yang bening."

(Saat untuk Cinta. bait 2, larik 2-3)

Simbol malam melambangkan kebodohan. Larik puisi yang memuat simbol malam adalah sebagai berikut.

"Maka mereka pandangi saja semua senja, semua warna yang beringsut menuju malam."

(Pada sebuah Senja. bait 3, larik 1-2)

Simbol kekuatan atau kekuasaan pada surat keputusan melambangkan sikap kekuatan dan kekuasaan untuk bertahan atau pengukuhan. Larik puisi yang memuat simbol kekuatan atau kekuasaan tampak sebagai berikut.

"Ucapmu sambil menghunjamkan surat keputusan"

(Di Planet Senen, Hollywoodku Sayang. bait 4, larik 1)

Simbol bayang-bayang menggambarkan kejahatan. Adapun simbol bayangbayang ini dapat ditemui pada larik puisi berikut.

"Aku bayang-bayang sirna dan maya di relung samudra lapar dan canda riamu." 
(Catatan Harian Diam-Diam. bait 2, larik 4-5)

Simbol bahagia menyatakan dan melambangkan kesenangan, kebaikan, berkah atas suatu perbuatan yang telah dilakukan. Larik puisi yang mengandung simbol bahagia adalah sebagai berikut.

"Kudengar engkau berbahagia menjalani hari-hari cinta, makan sepiring berdua berjoget riang di gubuk derita." (Catatan Harian Diam-Diam. bait 1, larik 15-17)

Simbol kecantikan menggambarkan daya tarik, keindahan, keharuman, kemasyhuran, secara spiritual keindahan budi pekerti dan perilaku. Adapun simbol kecantikan itu dapat ditemui pada larik puisi berikut.

"Tapi kecantikannya yang mendebarkan masih terasa."

(Cintailah Aku untuk Selamanya. bait 2, larik 3-4)

\section{Simbol-simbol pada Kategori Cosmos}

Simbol-simbol metaforis pada kategori cosmos mencakup: (a) simbol bumi, (b) simbol bulan, (c) simbol bintang, (d) simbol langit, (e) simbol matahari, dan (f) simbol dunia. Deskripsi wujud simbol metaforis kategori cosmos disajikan pada uraian contoh berikut.

Simbol bumi merupakan metafora yang melambangkan pergeseran kebudayaan. Adapun larik puisi yang menggunakan simbol bumi tersebut ada pada bagian berikut.

"Hasil bumi dan tambang serba berlimpah"

(Iklan Wisata Sebuah Biro Perjalanan. bait 1, larik 4-5)

Simbol bulan menggambarkan perilaku dan peranan yang pasif, kewanitaan, kegelapan, ketidaksadaran, keindahan yang terikat oleh siklus, dan berasosiasi dengan malam. Penggunaan simbol bulan terdapat pada larik puisi berikut.
“Rembulan di Den Pasar dan Sapu Tangan dari Bandung Selatan, siapakah yang menyanyikan semua itu?"

(Di Planet Senen, Hollywoodku Sayang. bait 2, larik 10-12)

Simbol bintang menggambarkan dan melambangkan harapan, nasib baik, keabadian, dan ketinggian spirit atau semangat. Adapun larik puisi yang memuat simbol bintang tersebut adalah sebagai berikut.

"Di bawah bintang (benarkah bintang, bintang kecil yang dinyanyikan ibu dulu?), kubaca lagi riwayat masa kanakmu, seperti tanah air yang tersipu.

(Syair Ngungun dan Keheranan. bait 4, larik 3-7)

Simbol langit merupakan metafora yang melambangkan sifat yang aktif, jantan, dan spirit. Larik puisi yang memuat simbol langit adalah sebagai berikut.

"aku termangu seperti bapak-bapak-

$\mathrm{ku}$ memandangi langit, terbentang indah"

(Sajak Anak Petani. bait 3, larik 1-2)

Simbol matahari melambangkan semangat, berani, aktif, jantan, dan kreatif. Adapun larik puisi yang memuat simbol matahari adalah sebagai berikut.

"Semua bergegas seperti matahari, meninggalkan jejak-jejak pada senja beribu warna di angkasa"

(Pada Sebuah Senja. bait 1, larik 3-4)

Simbol dunia melukiskan kerajaan yang menyatakan eksistensi yang terbuka, yang terdiri dari beberapa komponen. Simbol dunia yang digunakan pada lariklarik puisi sebagaimana terdapat pada ungkapan berikut.

"biar kusuguhkan secangkir teh atau sebaris puisi sambil bercakap menikmati dunia yang pedih ini"

(Indonesia, Sebuah Sisa. bait 3, larik 7-9) 


\section{Simbol-simbol pada Kategori Energi}

Simbol-simbol metaforis pada katego-

ri energi mencakup: (a) simbol awan, (b) simbol penerbangan, (c) simbol cahaya, (d) simbol panas, (e) simbol ombak, dan (f) simbol angin. Deskripsi wujud simbol metaforis kategori energi disajikan pada uraian contoh berikut.

Simbol awan melambangkan sifat perantara antara yang formal dan yang nonformal, atau sifat yang memberikan kesuburan atau pembawa pesan. Larik puisi yang memuat simbol awan adalah sebagai berikut.

"Pada saat-saat begini aku ingin tiduran saja di atas gumpalan awan..."

(Syair Pindah Rumah. bait 3, larik3)

Simbol penerbangan melambangkan level atau tingkatan yang harus dilalui. Larik puisi yang memuat simbol penerbangan adalah sebagai berikut.

"Wajah para tuan yang memungkinkan mereka naik pesawat terbang memperkenalkan peradaban dunia, musim dan bendera berbeda?"

(Bersama Para TKW. bait 1, larik 4-7)

Simbol cahaya melambangkan spirit, keunggulan dan perwujudan dan moralitas, intelektual dan kebaikan. Larik puisi yang mengandung simbol cahaya adalah sebagai berikut.

"Sungguh aku tak ingin berpuisi tentang embun, cahaya matahari di sela daun dan ombak yang berdebur pelan di pasir pantai"

(Catatan Harian Diam-Diam. bait 1, larik 8-11)

Simbol panas melambangkan kematangan baik secara biologi atau secara spiritual. Adapun larik puisi yang memuat simbol panas ini adalah sebagai berikut.

"menghirup lagi wangi daun-daun sehabis hujan

di rambut kekasih pada udara sepanas ini.."
(Belajar Menulis Sejarah. Bait 1, larik 7-9)

Simbol ombak melambangkan kemurnian yang menawarkan dua aspek yang berbeda atau dua kecendenrungan yang berbeda. Adapun simbol ombak sebagaimana terdapat pada larik puisi berikut.

“... dan ombak yang berdebur pelan di pasir pantai."

(Catatan Harian Diam-Diam. bait 1, larik 10-11)

Simbol angin melambangkan sikap kreatif yang menghasilkan kualitas yang murni dan suci. Adapun larik puisi yang memuat simbol angain tersebut adalah sebagai berikut.

"dan bersih dikeramasi angin sebab tak ada lagi..."

(The Hopelessness of Sleeping Beauty. bait 3, larik 3)

\section{Simbol-simbol pada Kategori Substance}

Simbol-simbol metaforis pada kategori substance mencakup: (a) simbol air, (b) simbol udara, dan (c) simbol salju. Deskripsi wujud simbol metaforis kategori substance disajikan pada uraian contoh berikut.

Simbol air melambangkan segala bentuk kehidupan yang kreatif, jantan, dan aktif. Larik puisi yang memuat simbol air adalah sebagai berikut.

“Di malam-malam tahajudku, kurabaraba dengan air mata"

(Timang-Timang. bait 4, larik 2)

Simbol udara melambangkan segala bentuk tentang hidup dan kehidupan yang aktif dan kreatif. Larik puisi yang memuat simbol udara adalah sebagai berikut.

“Tak ada cinta asmara untuk sajak, tinggal angin bertiup memenuhi udara."

(Pada Sebuah Senja. bait 1, larik 1-2) 
Simbol salju melambangkan kelembutan, kemurnia gagasan, kesucian, dan kelembutan. Larik puisi yang memuat simbol salju adalah sebagai berikut.

"Biru danau Sentani, puncak gunung berselimut salju abadi."

(Iklan Wisata sebuah Biro Perjalanan, bait 7, larik 3)

\section{Simbol-simbol pada Kategori Terestrial}

Simbol-simbol metaforis pada kategori terestrial mencakup: (a) simbol lembah, (b) simbol gunung, (c) simbol samudra, (d) simbol sungai, dan (e) simbol laut. Deskripsi wujud simbol metaforis kategori terestrial disajikan pada uraian contoh berikut.

Simbol lembah melambangkan keibuan, ketidaksadaran, dan atau kaitan dari segala aspek yang berbeda. Larik puisi yang memuat simbol lembah ini seperti yang terlihat berikut.

“Dari pucuk gunung dan lembahlembah

dari riuh pasar dan rumah-rumah, kami berbondong

memberikan suara dan harapan dan hati kami."

(Bukan untuk Kita, bait 1, larik 1-3)

Simbol gunung melambangkan kebesaran, kemegahan, keunggulan, keperkasaan, dan kemuliaan. Simbol gunung ini terdapat pada larik puisi berikut.

"Biru danau sentani, puncak gunung berselimut salju abadi."

(Iklan Wisata sebuah Biro Perjalanan, bait 7 , larik 3 )

Simbol samudra melambangkan kekuatan yang dinamis dan pernyataan yang transisional antara yang stabil (atau padat) dan yang tak berbentuk. Puisi yang menggunakan simbol samudra ini terlihat pada larik puisi berikut.

"Aku bayang-bayang sirna dan maya di relung samudra lapar dan canda riamu."
(Catatan Harian Diam-Diam, bait 2, larik 4-5)

Simbol sungai bermakna kekuatan yang kreatif, lambang kesuburan dan pengairan yang progresif, dan merupakan pengertian kehilangan dan pelupaan. Simbol sungai ini terdapat pada larik puisi berikut.

"Maka terimalah cinta ini, duka ini seperti kau terima air mata segala pencinta yang mengaliri laut dan sungaisungai hingga kapal-kapal bisa berlayaran ke negeri-negeri seberang."

(Pinangan Angin. bait 2, larik 3-7)

Simbol laut melambangkan keadaan air yang berubah-ubah, sebagai sumber kehidupan, dan merupakan tujuan. Simbol ini digunakan pada puisi dengan judul Iklan Wisata Sebuah Biro perjalanan.

"Maka terimalah cinta ini, duka ini seperti kau terima air mata segala pencinta yang mengaliri laut dan sungaisungai hingga kapal-kapal bisa berlayaran ke negeri-negeri seberang." (Pinangan Angin. bait 2, larik 3-7)

\section{Simbol-simbol pada Kategori Object}

Simbol-simbol metaforis pada kategori object mencakup: (a) simbol buku dan koran, (b) simbol jembatan, (c) simbol kursi, (d) simbol waktu, (e) simbol pakaian, (f) simbol pintu, (g) simbol emas, (h) simbol rumah, (i) simbol permata, (j) simbol pisau, (k) simbol mesin, (l) simbol musik, (m) simbol batu, (n) simbol kapal, (o) simbol baja, (p) simbol batu, (q) simbol pedang, (r) simbol jendela, dan (s) simbol sayap. Deskripsi wujud simbol metaforis kategori object disajikan pada uraian contoh berikut.

Simbol buku dan koran adalah pusat sumber informasi. Simbol buku dan koran tersebut terdapat larik-larik puisi berikut.

"Toko buku Monte Cristo telah jauh di belakangku." 
(Pameran Buku Jules Verne Di Toko Buku Monte Cristo. bait 9, larik 2)

"Kubaca dan kubaca lagi, kejumawaan yang sedih di koran-koran."

(Indonesia, Sebuah Sisa. bait 1, larik 1-2)

Simbol jembatan melambangkan hubungan antara yang dirasakan dan yang dipersepsi. Simbol ini sebagaimana terdapat pada larik puisi berikut.

"Kupandangi langit biru dan terbayang kembali jembatan merah."

(Di Jembatan Mirabeau. bait 1, larik 2-3)

Simbol kursi melambangkan kewenangan, kekuasaan, martabat, dan kedudukan. Simbol kursi tersebut sebagaimana terlihat pada larik puisi berikut.

"Dari sana kupandangi engkau saling berebut kursi dan menyusunnya sepanjang jalan sambil menghapus dengan tinju"

(Syair Ngungun dan Keheranan. bait 3, larik 7-9)

Simbol waktu bermakna sebagai 'angka' atau dihubungkan dengan gagasan gerakan perpetual, mekanisme otomatis, dan segala kreasi yang majikal. Penggunaan simbol waktu tersebut seperti terdapat pada larik puisi berikut.

"Kuajak engkau belajar merangkai detik memintal waktu jadi helaihelai sajadah tempat kita memasak, bermain, berniaga, dan berkantor di atasnya."

(Timang-Timang. bait 3, larik 1-4)

Simbol pakaian menyatakan lambang keseluruhan, kehormatan, dan kebanggaan. Penggunaan simbol pakaian tersebut sebagaimana tampak pada larik puisi berikut.

“... anak-anak kecil mengecat semuanya dengan warna merah putih, seperti warna pakaian seragam..."

(Menjelang Pemilu. bait 5, larik 3-4)
Simbol pintu melambangkan sesuatu yang bermakna kewanitaan, keterbukaan, dan jalan masuk. Adapun simbol pintu pada larik puisi-puisi itu adalah sebagai berikut.

"Aku akan datang padamu serupa turis, biar kau sambut aku di pintu rumahmu dengan senyum lebar dan mata berbinar, lalu kau peluk aku dengan hangat"

(Syair Ngungun dan Keheranan. bait 9, larik 2-6)

Simbol emas bermakna cahaya, unggul, mulia, dan tinggi, menurut ajaran Agama Hindu dan menurut Guenon. Adapun larik puisi yang menggunakan simbol emas tersebut adalah sebagai berikut.

"butir-butir pada kuning keemasan seperti kemerdekaan"

(Surat Paman Veteran pada Setengah Abad Kemerdekaan. bait 4, larik 2324)

Simbol rumah melambangkan kepribadian, masker, segala kearifan, kekuatan, dan spontanitas. Adapun larik puisi yang memuat simbol rumah tersebut adalah sebagai berikut.

"Di rumahku matahari terbit berkalikali tiap engkau tersenyum berpendaran di seluruh ruangan."

(Timang-Timang. Bait 2, larik 5-7)

Simbol permata melambangkan kebenaran spiritual dan pengetahuan tertinggi atau berharga. Larik puisi yang memuat simbol permata tersebut adalah sebagai berikut.

“Kutemui lagi Cortez yang menukar padang perburuan Indian dengan sepotong cermin, permata imitasi, ..." (Surat Paman Veteran pada Setengah Abad Kemerdekaan. bait 3, larik 3)

Simbol pisau melambangkan balas dendam, kematian, dan pengorbanan. Simbol pisau tersebut adalah sebagai berikut. 
"biar saat kita bertemu, tak kutemui lagi pisau di matamu"

(Indonesia, Sebuah Sisa. bait 3, larik 3)

Simbol mesin melambangkan makna konsumsi, pencernaan, dan reproduksi. Simbol ini dapat dijumpai pada larik puisi berikut.

"menjadi koboy, mesin perang dan bintang-bintang."

(Di Planet Senen, Hollywoodku Sayang. bait 2, larik 8)

Simbol musik bermakna keharmonisan dan penyesuaian. Simbol musik ini digunakan pada puisi ini seperti yang terlihat pada larik berikut.

“Telah kami ganti KTP di batin kami dengan padang prairi, musik country dan segelas Irish Coffee."

(Di Planet Senen, Hollywoodku Sayang. bait 2, larik 2-3)

Simbol batu melambangkan makna keabadian, kekerasan, dan integritas. Simbol batu tersebut adalah sebagai berikut.

"Tapi tak ada keringat buruh dengan es batu di gelas minumku."

(Catatan Harian Diam-Diam. bait 1, larik 4-5)

Simbol kapal melambangkan kesenangan dan kebahagiaan. Larik puisi yang memuat simbol kapal tersebut adalah sebagai berikut.

"yang mengaliri laut dan sungaisungai hingga kapal-kapal bisa berlayaran ke negeri-negeri seberang."

(Pinangan Angin. bait 2, larik 5-7)

Simbol baja menyatakan makna kekerasan. Larik puisi yang memuat simbol baja adalah sebagai berikut.

"mendapati anak-anak kini mengeras bagai baja hitam"

(NegeriBayang-Bayang. bait 1, larik 17)
Simbol batu melambangkan makna kepaduan, kekuatan, keadaan keutuhan, dan perdamaian. Simbol batu tersebut tampak pada larik puisi berikut.

"Rasanya kita seperti pembangunan, kata setumpuk bata dan batu-batu sambil tersenyum-senyum dan membagi kartu."

(Sesaat Sebelum Kebakaran. bait 4, larik 1-3)

Simbol pedang bermakna kehidupan, kematian, agresi spiritual, dan kekerasan. Larik puisi yang memuat simbol pedang adalah sebagai berikut.

"sejumput garam dan tentu saja tikaman pedang dan gempuran meriam."

(Surat Paman Veteran pada Setengah Abad Kemerdekaan. bait 3, larik 4)

Simbol jendela bermakna kesadaran, pembukaan, dan implikasi rasional. Larik puisi yang memuat simbol jendela tersebut adalah sebagai berikut.

"di sudut lemari, jalusi jendela atau ingatan tiba-tiba bertebaran kembali memenuhi udara"

(Seperti Pengakuan. bait 1, larik 8-9)

Simbol sayap bermakna spiritualitas, imajinasi, pikiran, intelegensi. Simbol sayap ini tampak pada larik puisi berikut.

"Maka kita lupakan Gibran dengan sayap-sayap patah yang bermimpi menjadi nabi."

(Timang-Timang. bait 2, larik 9-10)

\section{Simbol-simbol pada Kategori Living}

Simbol-simbol metaforis pada kategori living mencakup: (a) simbol bunga, (b) simbol buah-buahan, (c) simbol daun, dan (d) simbol pohon. Deskripsi wujud simbol metaforis kategori living disajikan pada uraian contoh berikut.

Simbol bunga bermakna kefanaan, keindahan, cindra-mata, atau pun ke- 
matian. Simbol bunga yang dimaksud adalah sebagai berikut.

"Satu dua kupu-kupu beterbangan di antara serbuk bunga."

(Belajar Menulis Sejarah. bait 3, larik 9-10)

Simbol buah-buahan bermakna benih asal kejadian dan hasrat keduniawian. Simbol tersebut bisa didapati pada larik puisi berikut.

"sajian di pesawat: ikan tuna saus mentega, nasi gurih panas, kue coklat, krim buah-buahan, segelas sari jeruk." (Bersama Para TKW. bait 3, larik 4-6)

Simbol daun bermakna kepuasan. Simbol daun ini dapat dijumpai pada larik puisi berikut.

"Kita seperti puisi ya? Bisik embun di sela daun pada kabut"

(Sesaat Sebelum Kebakaran Hutan. bait 1, larik 1)

Simbol pohon bermakna keunggulan, kualitas, alam manusia, pertumbuhan, perkembangbiakan, dan keabadian. Larik puisi yang memuat simbol pohon tersebut adalah sebagai berikut.

"Ketika pohon besar itu tumbang, ulat-ulat yang bertahun menggerogotinyapun bergegas menjelma kupukupu..."

(Catatan yang Tak Ingin Kubuat. bait 1, larik 1-3)

\section{Simbol Metafora pada Kategori Animate}

Simbol-simbol metaforis pada kategori animate mencakup: (a) simbol burung, (b) simbol kelelawar, dan (c) simbol kungang-kunang. Deskripsi wujud simbol metaforis kategori animate disajikan pada uraian contoh berikut.

Simbol burung bermakna pikiran dan imajinasai yang tinggi, kecepatan, proses spiritual, dan hubungan. Simbol burung tersebut tampak pada larik puisi berikut.
“Inilah waktu untuk kicau burung dan kupu-kupu seribu kepedihan menjelma lagu."

(Saat untuk Cinta. bait 1, larik 1-2)

Simbol kelelawar bermakna menjelang malam, kegelapan, kejahatan, keremangan, dan kekaburan. Simbol kelelawar tersebut terdapat pada larik puisi berikut.

"Beberapa kelelawar melintas di antara pepohonan dan rembang senja" (Sesaat Sebelum Kebakaran Hutan. bait 1, larik 3-4)

Simbol kunang-kunang bermakna penerangan, inspirasi, ide, dan gagasan. Simbol kunang-kunang tersebut terdapat pada larik puisi berikut.

“Beberapa kunang-kunang berkerlipan menggaris malam"

(Sesaat Sebelum Kebakaran Hutan. bait 2, larik 3-4)

\section{Simbol-simbol pada Kategori Human}

Simbol-simbol metaforis pada kategori human mencakup: (a) simbol tangan, (b) simbol tubuh, dan (c) simbol anak-anak, (d) simbol kematian, (e) simbol mata, (f) simbol kaki, (g) simbol rambut, (h) simbol dada, dan (i) simbol nyawa. Deskripsi wujud simbol metaforis kategori human disajikan pada uraian contoh berikut.

Simbol tangan bermakna aktivitas secara umum, seperti bekerja, menawarkan, melindungi, mendermakan, doa, dan per-

tahanan diri. Simbol tangan tersebut terdapat pada larik puisi berikut.

"Kuajar engkau mengukuhkan tangan dan kaki menjadi berani agar bisa kau tanam benih-benih kasih sayang setiap detik"

(Timang-Timang. bait 4, larik 6; bait 5, larik 1-2)

Simbol tubuh melambangkan perasaan yang tak pernah puas, kesakitan, dan kematian. Simbol tubuh yang dimaksud terlihat pada larik puisi berikut. 
“Ia pun bahagia, akrab dan nyaman seras terbenam di bagian tubuh kekasih yang terdalam."

(Menjelang Pemilu. bait 1, larik 8-9)

Simbol anak-(anak) melambangkan masa depan, panggung kehidupan, jiwa, dan kekuatan formatif. Simbol anak(anak) yang dimaksud terlihat pada paparan larik puisi berikut.

"Maka aku titipkan salam dari hatiku padamu, ana-anak ibuku..."

(Indonesia, Sebuah Sisa. bait 3, larik 1-2)

Simbol kematian bermakna akhir dari masa, sumber kehidupan, kebebasan yang tinggi, kemajuan atas evolusi, dematerialisasi, dan pupuk. Simbol kematian tersebut adalah sebagai berikut.

"soal dimusnahkannya satu kehidupan,

soal masa depan manusia yang dibekam."

(Air Mata Hujan. bait 2, larik 7-8)

Simbol mata bermakna tindakan spiritual, dan inteligensi. Simbol mata adalah sebagai berikut.

"bisa bangkit mengantar anak-anaknya ke masa depan dengan mata berbinar, ..."

(Surat Paman Veteran pada Setengah Abad Kemerdekaan. bait 4, larik 2728)

Simbol kaki bermakna perasaan yang bertentangan, penopang tubuh, dan sebagai jiwa. Metafora kaki yang digunakan itu terdapat pada larik puisi berikut.

"Kuajar engkau mengukuhkan tangan dan kaki menjadi berani agar bisa kau tanam benih-benih kasih sayang setiap detik"

(Timang-Timang. bait 4, larik 6; bait 5, larik 1-2)
Simbol rambut melambangkan kehormatan, mahkota, yang dicintai, dan yang didambakan. Simbol rambut tampak pada larik puisi berikut.

"di rambut kekasihku pada udara sepanas ini."

(Belajar Menulis Sejarah. Bait 1, larik 8-9)

Simbol dada bermakna ketabahan, kesabaran, perlindungan, dan keuletan. Simbol dada dapat dijumpai pada baris puisi berikut.

"segera membuka hati lebar-lebar biar panah asmara menancap tiba menenmbus dada."

(Menjelang Pemilu. bait 1, larik 1-3)

Simbol nyawa bermakna kehidupan, masa depan, dan kesabaran. Simbol nyawa dapat dijumpai pada baris puisi berikut.

"menjahit martabat yang tercabik dengan nyawanya"

(Surat Paman Veteran pada Setengah Abad Kemerdekaan. bait 4, larik 17)

\section{Simbol Metaforis yang Dominan dalam Puisi Agus R. Sarjono}

Dari sembilan kategori ruang persepsi tersebut dapat dinyatakan hal-hal berikut. Pertama, terdapat ketidakseimbangan antara jumlah yang diperoleh pada setiap kategori. Ketidakseimbangan itu disebabkan oleh sistem ekologi yang berinteraksi tidak seimbang. Dalam penelitian ini antara satu kategori dan kategori lainnya diperoleh jumlah simbol yang bervariasi, baik secara kualitatif maupun kuantitatif. Setiap kategori menunjukkan tingkat tertentu dalam pemunculannya. Pada kategori object terdapat prioritas utama dalam penggunaan simbol-simbol dalam puisi-puisi yang diteliti.

Hal itu menunjukkan bahwa simbolsimbol pada kategori object selalu muncul. Mungkin dalam hal itu sang penyair sangat sering berinteraksi dengan objek-objek 
di sekitar lingkungannya, sangat mudah ditemukan, dan sangat mudah dipakai sebagai analogi dan metafora dalam memberikan efek makna pada puisi-puisi yang diciptanya. Kecenderungan penyair dalam menggunakan simbol-simbol pada kategori object tersebut juga berarti bahwa persepsinya terhadap simbol-simbol yang mengacu pada object sangat tinggi. Ketinggian penggunaan simbol terhadap kategori object barangkali dipengaruhi oleh keadaan lingkungannya tempat simbolsimbol yang mengacu pada objek lebih banyak beriteraksi dengan kehidupan dan pengalaman penyair.

Simbol-simbol pada kategori human dan kategori being juga termasuk sering muncul, yakni pada kisaran antara 9 sampai dengan 11 simbol. Kategori-kategori cosmos, energy, dan terrestrial termasuk kategori cukup sering muncul dengan kisaran (5-6) simbol. Selanjutnya, simbolsimbol pada kategori-kategori substance, living, dan animate termasuk jarang dan sangat jarang muncul, yakni pada kisaran 3-4 simbol.

Kedua, temuan berikut yakni adanya kecenderungan penyair bahwa dalam menciptakan metafora memanfaatkan simbol-simbol yang mengacu pada kategori human dan kategori being. Hal itu menandakan bahwa sang penyair lebih banyak berkisah tentang manusia, perilaku-perilaku kesehariannya, dan karakterkarakter utama manusia (kejujuran, kesetiaan, kebenaran, kebahagiaan, keindahan, kecantikan, dll.) atau pun sebaliknya (keserakahan, ketamakan, kejahatan, kecurangan, pengkhianatan, dan sejenisnya) dan ke-ada-an.

Penyair lebih banyak menggunakan simbol yang mengacu pada kategori human dan kategori being daripada kategori object. Hal itu mungkin sebagai akibat makin banyaknya manusia dan makin beragamnya tingkah laku dan permasalahan yang diciptakan dan dihadapi oleh manusia. Nomina-nomina yang terdapat atau dimiliki manusia memiliki maknamakna tertentu.

Ketiga, kecenderungan pada kategori human sesudah kategori being dan kategori object dengan jumlah 9 simbol atau pada kisaran $13.85 \%$. Hal itu menandakan bahwa interaksi dan pengetahuan penyair terhadap metafora yang mengacu pada kategori human hanya $13.85 \%$. Interaksi dan persepsinya terhadap hal-hal yang bersifat kongkrit tentang manusia hanya menjangkau sejumlah simbol tersebut.

Keempat, kecenderungan pada kategori being sesudah kategori object dengan jumlah 11 simbol atau pada kisaran $16.92 \%$ lebih tinggi daripada kategori human. Hal itu menandakan bahwa interaksi dan pengetahuan penyair terhadap metafora yang mengacu pada kategori being cukup tinggi, yakni 16.92\%. Interaksi dan persepsinya terhadap hal-hal yang bersifat abstrak tentang karakter-karakter manusia dan alam menjangkau sejumlah simbol tersebut.

Kelima, kecenderungan pada kategori energi sesudah kategori human, being, dan object dengan jumlah 6 simbol atau pada kisaran $9.23 \%$. Hal itu menandakan bahwa persepsi sang penyair terhadap nomina yang memiliki predikasi bergerak hanya $9.23 \%$. Interaksi lingkungan yang mengacu pada predikasi bergerak berada pada jumlah persentase tersebut.

Keenam, kecenderungan pada kategori cosmos dan terrestrial sesudah kategori energy, human, being, dan object dengan jumlah yang sama, yakni 8 simbol atau pada kisaran $7.70 \%$. Lingkungan simbol pada kategori cosmos cukup jauh dari interaksi manusia, sehingga hal itu dapat dimaklumi tentang sedikitnya simbol pada kategori tersebut yang digunakan oleh sang penyair. Akan tetapi, lingkungan simbol pada kategori terrestrial lebih dekat dengan dunia dan persepsi sang penyair. Lingkungan terrestrial lebih dekat berinteraksi dengan manusia. Simbol yang memiliki sifat terhampar sudah cukup banyak. 
Namun, yang terdapat dalam puisi hanya sejumlah tersebut. Mungkin hal itu berarti bahwa hanya terbatas pada simbol-simbol tersebut persepsi sang penyair atau hanya terbatas pada simbol-simbol tersebut yang berinteraksi dengannya.

Ketujuh, kecenderungan pada kategori living sesudah kategori terrestrial, cosmos, energy, human, being, dan object dengan jumlah 4 simbol atau pada kisaran $6.15 \%$. Hal itu menandakan bahwa ruang persepsi sang penyair yang menunjukkan simbolsimbol yang sifatnya tumbuh-(tumbuhan) dan buah-(buahan) hanyalah 6.15\%. Akan tetapi, bila dilihat dari lingkungan yang berinteraksi, kategori-kategori itu masih tergolong miskin, sebab masih terdapat simbol-simbol yang maknanya universal belum terjangkau atau belum terpakai. Mungkin juga hal itu disebabkan keadaan lingkungan pada masa penciptaan puisipuisi itu simbol-simbol yang lebih dominan akrab dengan sang penyair adalah 6 simbol yang telah disebut sebelumnya, sehingga mereka lebih mengilhami penciptaan puisi-puisi metaforis.

Kedelapan, kecenderungan kategori semantik universal yang paling sedikit pemakaian simbol-simbolnya adalah kategori substance dan kategori animate dengan jumlah yang sama, yakni 3 simbol atau pada kisaran $4.61 \%$. Kecenderungan penyair pada dua jenis kategori semantik tersebut paling sedikit jika dibandingan dengan tujuh kategori yang telah disebutkan sebelumnya. Sedikitnya kecenderungan itu mungkin disebabkan terbatasnya simbol-simbol pada kategori substance dan animate yang berinteraksi dan memberikan persepsi pada penyair dalam proses penciptaan puisi-puisinya.

\section{SIMPULAN}

Metafora tidak dapat dilepaskan dalam penciptaan puisi oleh penyair yang teramati pada larik-larik yang menjadi bagian dari puisi. Metafora tersebut dapat ditemukan dalam bentuk simbol-simbol yang mengandung makna metaforis yang dapat mewakili ruang persepsi manusia. Sehubungan dengan itu, penelitian ini merupakan bentuk kajian terhadap ungkapan-ungkapan metaforis dalam puisipuisi (39 puisi) karya Agus R. Sardjono yang mewakili ruang persepsi manusia.

Berdasarkan hasil penelitian dapat dikemukakan bahwa dalam puisi-puisi karya Agus R. Sardjono terdapat simbolsimbol ungkapan metaforis yang mewakili ruang persepsi manusia. Ditemukan 65 simbol yang mengandung ungkapan metaforis yang tersebar pada sembilan jenis ruang persepsi manusia. Ungkapan metaforis tersebut dimaksudkan untuk memperoleh efek etis dan estetis dalam puisi. Efek etis dan estetis disampaikan penyair dengan menggunakan ungkapanungkapan metaforis yang melambangkan sesuatu yang kongkrit untuk tujuan yang abstrak atau pun sebaliknya untuk tujuan yang abstrak dengan menggunakan lambang-lambang yang kongkrit.

\section{UCAPAN TERIMA KASIH}

Ucapan terimakasih disampaikan kepada teman sejawat yang telah berkenan menjadi mitra diskusi dalam pemahaman permasalahan dalam artikel ini. Selanjutnya ucapan terima kasih diucapkan kepada reviewer anonim yang telah membaca, mengoreksi dan memberi masukan terhadap artikel ini. Semoga artikel ini dapat memperluas kajian puisi, khususnya kajian pada aspek stilistika atau gaya bahasa.

\section{DAFTAR PUSTAKA}

Achen, Sven Tito. 1978. Symbols Around Us. New York: Van Nostrand Reinhold Company.

Cirlot, J.E. 1962. A Dictionary of Symbols. Second edition. New York: Philosophical Library Inc.

Halley, Michael C. 1980. Concrete Abstraction: The Linguistic Universe of Metaphors. in Marvin K.L. Ching, Michael 
C. Halley and Ronald F. Lonsford (eds) Linguistic Persfective on Literature, London: Routledge \& Kegan Paul Ltd. Levin, Samuel R. 1977. The Semantics of Metaphor. Baltimore: The John Hopkins University.

Russel, Chirsthoper Reaske. 1966. How to Analyze Poetry. New York: Monarch Press.
Sardjono, Agus R. 2003. Suatu Cerita dari Negeri Angin: Sejumlah Sajak Asli dan Satu Sajak Palsu. Yogyakarta: Penerbit Jendela.

Wahab, Abdul. 2006a. Butir-Butir Linguistik. Surabaya: Airlangga University Press

Wahab, Abdul. 2006b. Isu Linguistik. Surabaya: Airlangga University Press.

Wahab, Abdul. 2006c. Teori Semantik. Surabaya: Airlangga University Press. 